\title{
Feeding habits of the fishes Euthynnus lineatus and Scomberomorus sierra (Perciformes: Scombridae) in the Eastern Tropical Pacific
}

Adriana Sandoval-Ramírez ${ }^{1}$, Genoveva Cerdenares-Ladrón de Guevara², Agustín Aucencio Rojas-Herrera ${ }^{3 *}$, Juan Violante-González ${ }^{3}$, Sergio García-Ibáñez ${ }^{3}$

\& Juan Carlos Hernández-Gómez ${ }^{4}$

1. Centro de Ciencias de Desarrollo Regional, Universidad Autónoma de Guerrero, Los Pinos s/n, Colonia El Roble, Acapulco, Guerrero, México, 39640; san_ramz@hotmail.com

2. Universidad del Mar, Campus Puerto Ángel Ciudad Universitaria, San Pedro Pochutla, Oaxaca, México, 70902; gcerdenares@gmail.com

3. Facultad de Ecología Marina, Universidad Autónoma de Guerrero, Gran Vía Tropical, número 20, Fraccionamiento Las Playas, Acapulco, Guerrero, México,39390; rojash56@hotmail.com, viojuang@yahoo.com.mx, sergariba@gmail.com

4. Unidad Académica de Matemáticas, Universidad Autónoma de Guerrero, Carlos E. Adame, número 54, Colonia Garita, Acapulco, Guerrero, México, 39350; jcarloshg@gmail.com

* Correspondence

Received 06-II-2020. Corrected 17-V-2020. Accepted 30-VII-2020.

\begin{abstract}
Introduction: Black skipjack, Euthynnus lineatus, and Pacific sierra, Scomberomorus sierra, are of great economic importance in the small-scale fishery of the Tropical Eastern Pacific and in particular in the study area. Objectives: The objectives of the present study were to assess the diet components of E. lineatus and S. sierra, as well as to evaluate the niche width, trophic level, and trophic overlap between the two species, by size and season. Methods: Biological samples were obtained weekly from small-scale fishery catches in Bahía de Acapulco, Mexico. The E. lineatus sampling period occurred from October 2016 to October 2017, whereas S. sierra was sampled from October 2016 to June 2018. The Prey-specific Index of Relative Importance (\% PSIRI) was used to evaluate the importance of each prey item in the diet of the predator. Levin's index $\left(\mathrm{B}_{\mathrm{i}}\right)$ was used as a measure of niche width. The Morisita-Horn index was used to evaluate diet overlap by size (juveniles or adults), by season (dry or wet), and between the two species. The trophic level (TL) of predators was calculated using the Cortés' method. Results: A total of 262 E. lineatus stomachs were analyzed (42\% were empty and $58 \%$ contained food) and a total of 209 S. sierra stomachs were analyzed (74.6\% were empty and $25.3 \%$ contained food). Of the total E. lineatus specimens sampled, 107 were juveniles and 155 were adults. Black skipjack juveniles fed on five food items and adults fed on 13 food items. Of the total S. sierra specimens sampled, 75 were juveniles and 134 were adults. Pacific sierra juveniles and adults fed on five food items. The diet of the two species comprised fish, mollusks, and crustaceans. The two species showed narrow niche width. The diet of juvenile and adult E. lineatus presented differences with growth, contrary to what was observed for juveniles and adults of $S$. sierra. There were no significant differences in diet by season for both species. The trophic overlap obtained between the two species was low. The trophic level calculated for both species indicated that are tertiary consumers. Conclusions: Black skipjack and Pacific sierra are tertiary predators and present a specialist behavior, feeding mainly on fish from the families Engraulidae and Clupeidae. Although a degree of similarity in the dietary food components of these species was observed, there was not a high degree of interspecific competition for food.
\end{abstract}

Key words: diet; black skipjack; Pacific sierra; niche width; trophic level; competition; Tropical Eastern Pacific.

Sandoval-Ramírez, A., Cerdenares-Ladrón de Guevara, G., Rojas-Herrera, A.A., ViolanteGonzález, J., García-Ibáñez, S., \& Hernández-Gómez, J.C. (2020). Feeding habits of the fishes Euthynnus lineatus and Scomberomorus sierra (Perciformes: Scombridae) in the Eastern Tropical Pacific. Revista de Biología Tropical, 68(4), 1073-1083. 
Black skipjack, Euthynnus lineatus, and Pacific sierra, Scomberomorus sierra (Family Scombridae), are fish that inhabit the pelagic-oceanic zone. They are distributed in the tropical and subtropical waters of the Tropical Eastern Pacific from California, USA, to Peru (Collette \& Nauen, 1983). They frequently form multispecific schools and are considered highly active fish that carry out seasonal migrations associated with feeding and reproduction (Collette \& Nauen, 1983).

Scombrids are of great economic importance and constitute the foundation of smallscale fisheries in several regions worldwide (Fischer et al., 1995). Although the scombrid fishery is generally more focused on tunas, skipjacks are very abundant, and due to their low price in local markets, they represent an accessible resource for the population. Due to its nutritional value, sierra is one of the most attractive species for consumers on the Mexican coast (Montemayor-López \& CisnerosMata, 2000).

According to previous trophic biology studies, scombrids are widely known as generalist opportunistic predators. That is, their niche width is composed of a wide variety of organisms at different levels on the food chain (Olson et al., 2016). Scombrids, along with dolphins, billfishes, sharks and other species, are found at the highest trophic levels, moving freely between habitats and transferring energy between food webs (Ménard, Labrune, Shin, Asine, \& Bard, 2006). When populations of top predators decrease can cause a cascade effect on the ecosystem, defined as a reciprocal effect between predator-prey that alters the abundance, biomass or productivity of a community or trophic level in more than one link in the trophic chain (Pace, Cole, Carpenter, \& Kitchell, 1999).

In general, feeding habits of fish represent an integration of many ecological components that include behaviour, condition, habitat use, niche overlap, energy intake, intraspecific and interspecific interactions. Thus, diet composition information of high-level predators is particularly important to understand the functional role of this species and to elaborate ecosystem models that consequently provides information that contributes to the management of fishing resources (Hyslop, 1980; Christensen \& Pauly, 1992; Caragitsou \& Papaconstantinou, 1993).

In the present study we characterize the diet of Black skipjack, Euthynnus lineatus, and Pacific sierra, Scomberomorus sierra, from a poorly studied area, Bahía de Acapulco. The specific objectives were i) to determine the niche width, ii) the trophic level, and iii) the trophic overlap between the two species, by size, that is juveniles and adults, and season, dry and wet.

\section{MATERIALS AND METHODS}

Study area: Bahía de Acapulco is located at (16 $52^{\circ}$ - $\left.16^{\circ} 41^{\prime} \mathrm{N} \& 9^{\circ} 29^{\prime}-100^{\circ} 11^{\prime} \mathrm{W}\right)$ in Guerrero, Mexico, in the Eastern Tropical Pacific. The climate in this area is characterized by a wet season extending from May to October and a dry season extending from November to April (Gutiérrez-Zabala \& Cabrera-Mancilla 2012). Some of the important characteristics of Bahía de Acapulco is its proximity to two coastal lagoons (Laguna de Coyuca and Laguna de Tres Palos), the flow of several streams to the bay, the different types of substrate found within the bay (sandy, with patches of coral reefs, rocky reefs, islets and seamounts, resulting in a highly heterogeneous system (PalaciosSalgado et al. 2014).

Sampling: Biological samples were obtained weekly, according to the species availability in the catches made by the small-scale fishery in Bahía de Acapulco. The E. lineatus sampling period occurred from October 2016 to October 2017, whereas S. sierra was sampled from October 2016 to June 2018. The total length (TL) and total weight (TW) of all organisms were obtained. Stomachs were extracted and frozen for later analysis.

Laboratory work: Stomach contents were separated by prey type; each type was counted, weighed, and identified to the lowest possible 
taxonomic level using specialized keys according to the prey digestion state. Fish at an initial state of digestion were identified using the keys by Allen and Robertson (1994) and Fischer et al. (1995). Fish at an advanced state of digestion were identified based on vertebral characteristics, using keys by Clothier (1950).

Data analysis: Samples were classified as juveniles or adults, based on the work by Schaefer (1987), who reported that the size at first maturity of E. lineatus was $45.7 \mathrm{~cm}$ TL (total length), and on the results by AguirreVillaseñor, Morales-Bojórquez, Morán-Angulo, Madrid-Vera, \& Valdez-Pineda (2006), who indicated that the size at first maturity of $S$. sierra was $44.3 \mathrm{~cm}$ FL (fork length). Samples were divided into two characteristic seasons of the area: dry (November to April) and wet (May to October). Sex was not included due to the absence of mature gonads in the collected specimens.

Sample size: Prey accumulation curves were constructed to determine whether sample sizes were representative of E. lineatus and $S$. sierra diets. Curves were created using the Vegan package (Oksanen, 2016) in R (R Core Team, 2015), which consists in randomly sampling the species richness found in the stomachs of the predators and graphing the average accumulated prey according to the number of analyzed stomachs. A linear regression of the last four points of the curve was performed to verify whether the best adjusted slope was significantly different from a zero slope line; this indicated that the curve had reached the asymptote (Bizzarro, Robison, Rinewalt, \& Ebert, 2007).

Diet composition: The Frequency of Occurrence $(\%$ FO $=$ number of stomachs containing prey i / total number of stomachs containing food * 100), the Numeric Method $(\% \mathrm{~N}=$ number of prey $\mathrm{i} /$ total number of prey * 100), and the Gravimetric Method (\% W = weight of prey i / total weight of prey * 100), were used to analyzed the diet composition
(Hyslop, 1980). The Prey-specific Index of Relative Importance (\% PSIRI) (Brown, Bizzarro, Cailliet, \& Ebert, 2011) was used to evaluate in an integrated manner the importance of each prey item in the diet of the predator. This index was calculated in the following manner:

$$
\% \text { PSIRI }_{i}=\frac{\% \boldsymbol{F O}_{i} *\left(\% \boldsymbol{P N _ { i }}+\% \boldsymbol{P W _ { i }}\right)}{2}
$$

Where $\% \mathrm{FO}_{\mathrm{i}}$ is the Frequency of Occurrence and $\% \mathrm{PN}_{\mathrm{i}}$ and $\% \mathrm{PW}_{\mathrm{i}}$ are the indices of Preyspecific Abundance $\left(\% \mathrm{PA}=\sum \% \mathrm{~A}_{\mathrm{ij}} / \mathrm{n}_{\mathrm{i}}\right)$, where $\% \mathrm{~A}_{\mathrm{ij}}$ is the abundance (expressed in number or weight) of the prey i category in the $\mathrm{j}^{\text {th }}$ stomach, $\mathrm{n}_{\mathrm{i}}$ is the number of stomachs containing prey $i$, and $n$ is the total number of stomachs.

Niche breadth: Levin's index $\left(\mathrm{B}_{\mathrm{i}}\right)$ (Krebs, 1999) was used as a measure of niche width. This index evaluates quantitatively whether organisms are generalists (varied food sources without selection) or specialists (preference for certain prey). It was calculated as follows:

$$
B_{i}=\frac{1}{n-1\left\{\left(\frac{1}{\sum P_{i j^{2}}}\right)-1\right\}}
$$

Where $\mathrm{P}_{\mathrm{ij}}$ is the proportion of the diet predator $\mathrm{i}$ that includes prey $\mathrm{j}$, and $\mathrm{n}$ is the number of prey categories. The predator is considered a specialist if $\mathrm{B}_{\mathrm{i}}$ is close to zero and a generalist if $\mathrm{B}_{\mathrm{i}}$ is close to one.

Diet overlap by size and season: The EcosimR package for niche superposition (Gotelli, Hart, \& Ellison, 2014) was used to evaluate diet overlap by size (juvenile or adult) and season (dry or wet), as well as between the two predators. The package was modified by using the Morisita-Horn index (Horn, 1966) instead of the Pinkas index due to Morisita's measure of overlap gives the most accurate results (Smith \& Zaret, 1982). The MorisitaHorn index values range from zero, when diets are completely different, to one, when 
diets are identical. It was calculated using the following equation:

$$
C \lambda=\frac{2 \sum_{i=\mathbf{1}}^{n}\left(\boldsymbol{P}_{x i} * \boldsymbol{P}_{y i}\right)}{\sum_{i=\mathbf{1}}^{n} \boldsymbol{P}_{x i^{2}}+\sum_{i=1}^{n} \boldsymbol{P}_{y i^{2}}}
$$

Where $\mathrm{P}_{\mathrm{xi}}$ is the proportion of prey $\mathrm{i}$ from the total number of prey consumed by predator $\mathrm{x}$; $\mathrm{P}_{\mathrm{yi}}$ is the proportion of prey $\mathrm{i}$ from the total number of prey consumed by predator $y$; and $n$ is the total number of prey. To assess whether differences in diet were the result of biological processes and not random, we compared a null distribution with the overlap index values. A total of 1000 simulations of the index were performed using the RA3 randomization algorithm in EcosimR (Gotelli, Hart, \& Ellison, 2014).

Trophic level: The trophic level (TL) of predators was calculated using the method proposed by Cortés (1999), calculated as follows:

$$
N T_{i}=1+\left(\sum_{j=1}^{n} P_{j} \times N T_{j}\right)
$$

Where $\mathrm{P}_{\mathrm{j}}$ is the proportion of each prey category in the diet of the predator and $\mathrm{NT}_{\mathrm{j}}$ is the trophic level of each prey category $\mathrm{j}$. The trophic levels of prey were obtained from the database of the Sea Around Us project (http://www.seaaroundus.org/data/\#/marine-trophic-index).

\section{RESULTS}

The size of E. lineatus specimens ranged between 33.8 and $59 \mathrm{~cm} \mathrm{TL}$, the average length was $45.6 \mathrm{~cm}$ TL and standard deviation was 6.3 $\mathrm{cm}$ TL. While, $S$. sierra specimens measured between 34 and $65.5 \mathrm{~cm} \mathrm{TL}$, the average length was $51.2 \mathrm{~cm}$ TL and standard deviation was $10.1 \mathrm{~cm} \mathrm{TL}$.

Diet composition: A total of $262 \mathrm{E}$. lineatus stomachs were analyzed (42\% were empty and $58 \%$ contained food) and a total of $209 S$. sierra stomachs were analyzed $(74.6 \%$ were empty and $25.3 \%$ contained food) (Table 1 ).

The prey accumulation curve of $E$. lineatus became asymptotic at stomach number 89 , with $94.3 \%$ of the items that theoretically are expected to find, this indicates that the number of stomachs analyzed was sufficient to represent the diet $(\mathrm{P}>0.05)$. The prey accumulation

TABLE 1

Stomach contents analysis of the black skipjack Euthynnus lineatus and the Pacific sierra

\begin{tabular}{|c|c|c|c|c|c|c|}
\hline & \multicolumn{3}{|c|}{ Euthynnus lineatus } & \multicolumn{3}{|c|}{ Scomberomorus sierra } \\
\hline & Stomachs with food & Empty stomachs & $\mathrm{N}$ & Stomachs with food & Empty stomachs & $\mathrm{N}$ \\
\hline Oct-2016 & 1 & 2 & 3 & 1 & 2 & 3 \\
\hline Nov-2016 & 5 & 1 & 6 & 3 & 1 & 4 \\
\hline Jan-2017 & 26 & 13 & 39 & 3 & 4 & 7 \\
\hline Feb-2017 & 20 & 24 & 44 & 3 & 34 & 37 \\
\hline Mar-2017 & 13 & 6 & 19 & 20 & 27 & 47 \\
\hline Apr-2017 & 33 & 2 & 35 & 4 & 2 & 6 \\
\hline May-2017 & 3 & 1 & 4 & 7 & 36 & 43 \\
\hline Jun-2017 & 5 & 6 & 11 & & & \\
\hline Jul-2017 & 8 & 21 & 29 & 2 & 1 & 3 \\
\hline Aug-2017 & 3 & 8 & 11 & & & \\
\hline Sep-2017 & 1 & 3 & 4 & & & \\
\hline Oct-2017 & 34 & 23 & 57 & 2 & & 2 \\
\hline Jan-2018 & & & & 3 & 17 & 20 \\
\hline Feb-2018 & & & & 3 & & 3 \\
\hline Apr-2018 & & & & 2 & 31 & 33 \\
\hline Jun-2018 & & & & & 1 & 1 \\
\hline TOTAL & 152 & 110 & 262 & 53 & 156 & 209 \\
\hline
\end{tabular}
Scomberomorus sierra in the Tropical Eastern Pacific 
curve of S. sierra became asymptotic at stomach number 28 , with $83.1 \%$ of the items that theoretically are expected to find, however, the analyzed sample size was close to being sufficient for an adequate diet description ( $\mathrm{P}<$ $0.05)$. The overlap value obtained between the two species was low, which indicated that the diets were different $(\mathrm{C} \lambda=0.2)$.

Diet variation by size: Of the total number of E. lineatus specimens sampled, 107 were juveniles and 155 were adults. Black skipjack juveniles fed on five food items. The most important prey in the diet were unidentified fish (\% PSIRI $=57.4)$ and fish from the families Engraulidae (\% PSIRI $=30.1)$ and Clupeidae $(\%$ PSIRI $=12.3)($ Table 2$)$.

Black skipjack adults fed on 13 food items. The most important items in the diet were the family Engraulidae (\% PSIRI $=39.9)$, unidentified fish $(\%$ PSIRI $=34.4)$, and the family Clupeidae $(\%$ PSIRI $=14.7)($ Table 2$)$. According to the Morisita-Horn index, there was no significant overlap between juveniles and adults of $E$. lineatus $(\mathrm{C} \lambda=0.3)$.

Of the total number of $S$. sierra specimens sampled, 75 were juveniles and 134 were adults. Pacific sierra juveniles fed on five food items. The most important items in the diet were unidentified fish $(\%$ PSIRI $=66.8)$, unidentified crustaceans $(\%$ PSIRI $=17.6)$, and the families Engraulidae (\% PSIRI $=9.6)$ and Clupeidae $(\%$ PSIRI $=5.8)($ Table 3$)$.

Pacific sierra adults fed on five food components. The most important prey in the diet were unidentified fish $(\%$ PSIRI $=71.7)$, unidentified crustaceans $(\%$ PSIRI $=15.1)$, and the families Engraulidae (\% PSIRI $=8.5)$ and Clupeidae $(\%$ PSIRI $=4.5)$ (Table 3$)$. According to the Morisita-Horn index, there was high diet overlap between S. sierra juveniles and adults $(\mathrm{C} \lambda=0.9)$.

Seasonal variations in diet: A total of 143 stomachs of E. lineatus were collected during the dry season and 119 stomachs were collected

TABLE 2

Diet composition of the black skipjack Euthynnus lineatus in the Tropical Eastern Pacific

\begin{tabular}{|c|c|c|c|c|c|c|c|c|}
\hline \multirow[b]{2}{*}{ Prey } & \multicolumn{4}{|c|}{ Juveniles } & \multicolumn{4}{|c|}{ Adults } \\
\hline & $\% \mathrm{FO}$ & $\% \mathrm{~N}$ & $\% \mathrm{~W}$ & $\%$ PSIRI & $\% \mathrm{FO}$ & $\% \mathrm{~N}$ & $\% \mathrm{~W}$ & $\%$ PSIRI \\
\hline \multicolumn{9}{|l|}{ MOLLUSCA } \\
\hline Bivalvia & & & & & 1.98 & 0.19 & 0.01 & 1.98 \\
\hline \multicolumn{9}{|l|}{ PISCES } \\
\hline Family Engraulidae & 30.95 & 45.31 & 38.35 & 29.06 & 33.66 & 18.21 & 16.51 & 14.24 \\
\hline Anchoa spp. & 2.38 & 6.25 & 0.54 & 1.09 & 39.60 & 55.09 & 39.04 & 24.65 \\
\hline Centegralis mysticetus & & & & & 5.94 & 0.75 & 1.08 & 1.07 \\
\hline \multicolumn{9}{|l|}{ Family Clupeidae } \\
\hline Lile stolifera & & & & & 4.95 & 1.68 & 2.98 & 1.99 \\
\hline Lile sp. & & & & & 15.84 & 6.91 & 8.13 & 5.21 \\
\hline Opisthonema libertate & 2.38 & 1.56 & 11.91 & 2.38 & 7.92 & 0.84 & 0.94 & 4.30 \\
\hline Opisthonema sp. & 11.90 & 7.81 & 2.35 & 9.98 & 9.90 & 3.36 & 3.24 & 3.21 \\
\hline Family Exocoetidae & & & & & 0.99 & 0.56 & 0.28 & 0.37 \\
\hline Fodiator acutus rostratus & & & & & 0.99 & 0.09 & 0.33 & 0.99 \\
\hline Family Serranidae & & & & & 1.98 & 0.28 & 0.37 & 0.12 \\
\hline Fish larvae & & & & & 7.92 & 7.38 & 3.92 & 7.45 \\
\hline Unidentified fish & 59.52 & 39.06 & 46.86 & 57.50 & 49.50 & 4.67 & 23.17 & 34.42 \\
\hline TOTAL & 107.1 & 100 & 100 & 100 & 181.1 & 100 & 100 & 100 \\
\hline
\end{tabular}

Where $\%$ FO $=$ Frequency of Occurrence, $\% \mathrm{~N}=$ Numerical method, $\% \mathrm{~W}=$ Gravimetric method and $\%$ PSIRI $=$ PreySpecific Index of Relative Importance. 
TABLE 3

Diet composition of the Pacific sierra Scomberomorus sierra in the Tropical Eastern Pacific

\begin{tabular}{|c|c|c|c|c|c|c|c|c|}
\hline \multirow[b]{2}{*}{ Prey } & \multicolumn{4}{|c|}{ Juveniles } & \multicolumn{4}{|c|}{ Adults } \\
\hline & $\% \mathrm{FO}$ & $\% \mathrm{~N}$ & $\% \mathrm{~W}$ & $\%$ PSIRI & $\% \mathrm{FO}$ & $\% \mathrm{~N}$ & $\% \mathrm{~W}$ & $\%$ PSIRI \\
\hline \multicolumn{9}{|l|}{ CRUSTACEA } \\
\hline Unidentified crustaceans & 17.65 & 15.79 & 0.90 & 17.65 & 15.15 & 10.87 & 5.27 & 15.15 \\
\hline \multicolumn{9}{|l|}{ PISCES } \\
\hline Family Engraulidae & 5.88 & 5.26 & 17.96 & 5.88 & 9.09 & 15.22 & 13.78 & 7.39 \\
\hline Anchoa spp. & 5.88 & 5.26 & 4.06 & 3.75 & 3.03 & 2.17 & 0.16 & 1.19 \\
\hline \multicolumn{9}{|l|}{ Family Clupeidae } \\
\hline Opisthonema libertate & 5.88 & 10.53 & 35.20 & 5.88 & & & & \\
\hline Opisthonema sp. & & & & & 6.06 & 17.39 & 11.13 & 4.52 \\
\hline Unidentified fish & 70.59 & 63.16 & 41.88 & 66.84 & 75.76 & 54.35 & 69.66 & 71.75 \\
\hline TOTAL & 105.8 & 100 & 100 & 100 & 109 & 100 & 100 & 100 \\
\hline
\end{tabular}

$\% \mathrm{FO}=$ Frequency of Occurrence, $\% \mathrm{~N}=$ Numerical method, $\% \mathrm{~W}=$ Gravimetric method and $\%$ PSIRI $=$ Prey-Specific Index of Relative Importance.

during the wet season. During the dry season, black skipjack fed mainly on the family Engraulidae (\% PSIRI $=39.5)$, unidentified fish $(\%$ PSIRI $=32.6)$, and the family Clupeidae $(\%$ PSIRI $=16.4)$. During the wet season, black skipjack fed mainly on unidentified fish $(\%$ PSIRI $=57)$ and the families Engraulidae $(\%$ PSIRI $=31.2)$ and Clupeidae $(\%$ PSIRI $=$ 9.8) (Fig. 1).

A total of 157 stomachs of $S$. sierra were collected during the dry season, whereas 52 stomachs were collected during the wet season. The most important food items during the dry season were unidentified fish (\% PSIRI $=70.3)$, unidentified crustaceans $(\%$ PSIRI $=$ 20.5), and the families Engraulidae (\% PSIRI = 5.3) and Clupeidae (\% PSIRI = 3.8). The main diet items during the wet season were unidentified fish $(\%$ PSIRI $=69.1)$ and the families Engraulidae (\% PSIRI $=21.7)$ and Clupeidae $(\%$ PSIRI = 9) (Fig. 1). There was high trophic overlap between the seasons for the two species $(\mathrm{C} \lambda=0.6$ and $\mathrm{C} \lambda=0.9$, respectively).

Niche width: Values of Levin's index $\left(\mathrm{B}_{\mathrm{i}}\right)$ obtained for the two species were below

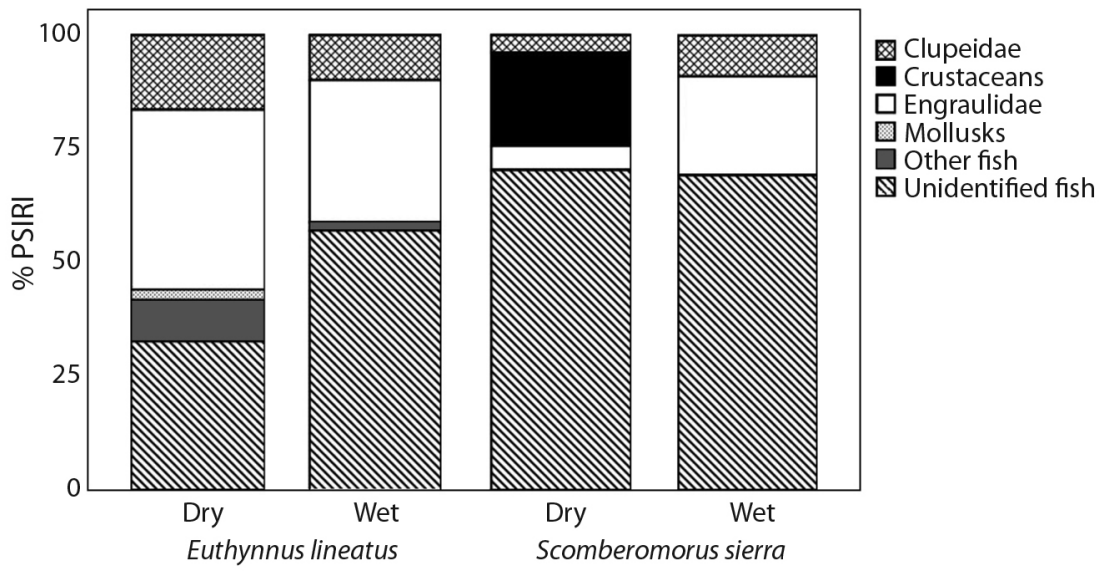

Fig. 1. Prey-Specific Index of Relative Importance (PSIRI) of the black skipjack Euthynnus lineatus and the Pacific sierra Scomberomorus sierra in the Tropical Eastern Pacific, during dry and wet season. 
0.6 for juveniles as well as for adults. Values found for $E$. lineatus were 0.4 for juveniles and 0.1 for adults, whereas for $S$. sierra values were 0.3 for juveniles and 0.4 for adults, which indicated that the two species are specialist predators.

Trophic level: The trophic levels calculated were 4.2 for E. lineatus juveniles and 4.1 for E. lineatus adults. The trophic level of $S$. sierra was 4 for juveniles and adults. Results found for the two species placed them as tertiary predators.

\section{DISCUSSION}

Diet composition: Black skipjack and Pacific sierra fed mainly on fish. The most important items in the diet were unidentified fish (with an advanced state of digestion) and the families Engraulidae and Clupeidae. These results coincide with what has been previously reported for the two species. For example, according to Chiou and Lee (2004), fish comprised $90 \%$ of the general diet of E. affinis. Griffiths, Kuhnert, Fry, \& Manson (2009) reported that pelagic clupeids and demersal fish were the main food components in the diet of that same species. Bahou et al. (2007) found that $E$. alletteratus fed on 23 prey taxa, including mainly flying fish, squid, and crustaceans. Ruíz-Pérez, Cerdenares-Ladrón de Guevara, López-Herrera, \& Altamirano-Ramírez (2016) indicated that $E$. lineatus feed mainly on crustaceans in the coast of Oaxaca. Miranda-Delgado et al. (2019) found that the E. lineatus trophic spectrum included 14 prey items in the study area, among which were fish, crab, penneid larvae, mollusk larvae, isopods, ostracods, juvenile squid, amphipods, and polychaetes.

Artunduaga (1972) reported that S. sierra is a carnivorous fish found at the upper levels of the food chain, whose existence depended mainly on planktivorous fish. Previous results for this species coincide with the present study in that it consumed mainly small pelagic fish that form dense schools, especially anchovies and sardines (Fischer et al., 1995;
Moreno-Sánchez, Quiñonez-Velázquez, AbitiaCárdenas, \& Rodríguez-Romero, 2012).

One of the most notable differences between the present study and what has been reported in previous studies is that the E. lineatus diet did not include cephalopods and crustaceans, and the diet of $S$. sierra did not include cephalopods, which could be related to geographical variations in the abundance and availability of prey on which these species feed (Rojas-Herrera, Mascaró, \& ChiappaCarrara, 2004).

It should be mentioned that a considerable proportion of stomachs of the two studied species were found empty or with a large proportion of contents at an advanced state of digestion. Several factors can influence the vacuity including the type of fishing, timing of capture and gastric emptying rates, influenced at the same time by the size of specimens, environmental temperature, and chemical properties of ingested prey (Cortés, Papastamatiou, Carlson, Ferry, \& Wetherbee, 2008; Wetherbee, Cortés, \& Bizarro, 2012; FloresMartínez, Torres-Rojas, Galván-Magaña, \& Ramos-Miranda, 2016; Leigh, Papastamatiou, \& German, 2017; Ehemann, Abitia-Cardenas, Navia, Mejía-Falla, \& Cruz-Escalona, 2019). Arrington et al. (2002) indicated that organisms with nocturnal feeding habits and piscivorous predators show a larger percentage of empty stomachs compared with fish with diurnal habits that prefer other food categories. Schaefer (1984) showed that gastric evacuation times are faster for scombrids than for most other fishes. This would explain the high frequency of fish and crustaceans at an advanced state of digestion found in both species, which made identification difficult.

Diet variations by size: In the present study, although fish constituted the largest proportion of the diet of juveniles and adults, we observed that adult fish presented a wider diet that included other fish groups such as flying fish and grunts, as well as fish larvae. In this regard, Bahou et al. (2007), explained three factors involved in size-based feeding 
strategies of E. alletteratus: (i) juveniles are constrained by their small size to take relatively small fish as prey; (ii) only following a probable period of initial growth it can switch to feeding on both crustaceans and fish, and (iii) adults tend to prefer consuming fish to crustaceans or cephalopods. Likewise, Griffiths et al. (2009) observed that the diet of small and medium sized of E. affinis (400-580 $\mathrm{mm}$ long) consisted mainly in small pelagic crustaceans (stomatopod larvae and brachyura megalopa) and fish larvae (engraulids, clupeoids, dactylopterids, monacanthids, and tetraodontids); whereas large fish ( > $580 \mathrm{~mm}$ ) consumed mainly larger specimens belonging to a different set of teleost prey (carangids, Trachurus declivis, belonids and Sardinops sagax). Changes in diet according to size may be simply attributable to evolution in feeding habits with increasing size of predator and provide evidence that size-based feeding strategies of scombrids may be related to limiting factors other than mouth-gape morphology, such as prey availability and behavioural differences of both predators and prey (Ménard et al., 2006; Bahou et al., 2007). In addition, the presence of fish during development may be due to the fact that they provide more energy for faster growth (Saucedo-Lozano et al., 2012).

Bakhoum (2007) indicated that teleosts were the most important food item for S. commerson of all sizes. Naughton and Saloman (1981) reported that fish occurred in $74 \%$ of the stomachs of $S$. cavalla, and invertebrates were of minor importance in the juvenile mackerel diet. Also, they reported that fishes occurred in $95 \%$ of the stomachs of $S$. maculatus, and invertebrates (squid) had a frequency of occurrence of $6 \%$. Naughton and Saloman (1981) explained that the smaller size and diameter of engraulids (Anchoa sp.) would be more readily ingested by juvenile predators with smaller mouth parts. No differences in diet were found between $S$. sierra juveniles and adults. However, the highly proportion of unidentified fish in its diet, represents uncertainty regarding dietary changes that this species might present with growth.
Seasonal variations in diet: Griffiths et al. (2009) pointed out that the season is the most important factor explaining variability in the diet of E. affinis. Bahou et al. (2007) indicated that E. alletteratus respond to seasonal changes in food availability, which reflects the opportunistic behaviour and trophic adaptability, allowing them to take advantage of the most readily available prey in the environment at any time. The diet of E. lineatus and S. sierra comprised the same prey groups during the wet and dry seasons. In the study area, Rojas-Herrera et al. (2004) also reported that two species of lutjanids (Lutjanus peru and L. guttatus), did not show seasonal qualitative variations in the use of the different components of their diets. They explained that the availability of prey in each region is what determines the feeding of these species, rather than the selection of prey. Likewise, Hernández-Aguilar, Abitia-Cárdenas, Moreno-Sánchez, Arellano-Martínez, \& González-Rodríguez (2012) reported that the sailfish Istiophorus platypterus, there were no differences in prey preference between the warm and cold seasons. They infer that in the southern Mexican Pacific region there is stability in prey abundance caused by the oceanographic characteristics of the area. In this sense, the feeding behavior of E. lineatus and $S$. sierra seems to depend on the most readily available preys, which are sufficiently diverse and abundant to allow their coexistence (RojasHerrera et al., 2004).

Niche width: Among scombrids, tunas are widely known as generalist opportunistic predators that consume a wide prey spectrum at different trophic levels, which allows them to move freely among habitats (Olson et al., 2016). However, according to the FAO (1994), the black skipjack is not considered a "highly migratory" species, although it carries out movements associated with continental platforms. This probably leads to its diet containing epipelagic as well as demersal prey (Griffiths et al., 2009).

According to Levin's index, E. lineatus and S. sierra are specialist predators, because 
their diets are narrow, with marked preference for a few prey species (anchovies and sardines). This behavior has been observed by other authors, who have also reported opportunistic behavior in these two species. This allows them to take advantage of the most easily available prey in the environment at a given time (Bahou et al., 2007; Moreno-Sánchez et al., 2012).

Trophic level: The consumption of species at different trophic levels in the food chain resulted in E. lineatus and S. sierra occupying relatively high trophic positions; this indicated that the two species act as tertiary consumers, or mesopredators, in the food web (Cortés, 1999). The energy transfer from lower trophic levels to upper levels and vice versa that these species present mean that their predatory habits could be used to detect important changes in the structure of the ecosystem (Olson et al., 2014).

According to our results, we can conclude that $E$. lineatus and $S$. sierra are tertiary predators and present specialist behavior, feeding mainly on fish from the families Engraulidae and Clupeidae. Moreover, although a degree of similarity in the dietary food components of these species was observed, there was not a high degree of interspecific competition for food.

Ethical statement: authors declare that they all agree with this publication and made significant contributions; that there is no conflict of interest of any kind; and that we followed all pertinent ethical and legal procedures and requirements. All financial sources are fully and clearly stated in the acknowledgements section. A signed document has been filed in the journal archives.

\section{ACKNOWLEDGMENTS}

The authors thank the fishermen who caught the fishes. Reviewers contributed to the improvement of this manuscript. The Consejo Nacional de Ciencia y Tecnología (CONACYT) provided a scholarship to A.S.R.

\section{RESUMEN}

Hábitos alimentarios de los peces Euthynnus lineatus y Scomberomorus sierra (Perciformes: Scombridae) en el Pacífico Tropical Oriental. Introducción: El barrilete negro, Euthynnus lineatus, y la sierra del Pacífico, Scomberomorus sierra, son peces que presentan gran importancia económica en la pesca artesanal del Pacífico Tropical Oriental y de manera particular en el área de estudio. Objetivos: Los objetivos del presente trabajo son determinar los componentes alimentarios de la dieta de E. lineatus y $S$. sierra, así como determinar la amplitud del nicho, el nivel trófico y el traslape trófico entre ambas especies, por tallas y por temporada climática. Métodos: Las muestras biológicas se obtuvieron semanalmente de las capturas realizadas por las pesquerías de pequeña escala llevadas a cabo en la Bahía de Acapulco. El periodo de muestreo de E. lineatus se realizó desde octubre 2016 hasta octubre 2017, mientras que el de $S$. sierra de octubre 2016 hasta junio 2018. El Índice de Importancia Relativa Específica de la Presa (\% PSIRI) se usó para evaluar la importancia de cada ítem presa en la dieta del depredador; el índice de Levin $\left(\mathrm{B}_{\mathrm{i}}\right)$ se usó como una medida de la amplitud del nicho; el índice de Morisita-Horn se usó para evaluar el traslape entre las dietas por talla (juveniles y adultos), por temporada climática (seca y lluviosa) y entre las dos especies. El nivel trófico (TL) de los depredadores fue calculado usando el método de Cortés. Resultados: Se analizaron en total 262 estómagos de E. lineatus (42\% vacíos y $58 \%$ con alimento) y 209 estómagos de $S$. sierra ( $74.6 \%$ vacíos y $25.3 \%$ con alimento). Del total de organismos muestreados de E. lineatus, 107 se consideraron organismos jóvenes y 155 adultos. Los jóvenes de barrilete se alimentaron de 5 ítems alimentarios y los adultos se alimentaron de 13. En el caso de $S$. sierra, 75 organismos se consideraron jóvenes y 134 adultos. Los jóvenes y adultos de sierra se alimentaron de cinco ítems alimentarios. La dieta de ambas especies se compone por peces, moluscos y crustáceos. Las dos especies presentaron una amplitud del nicho trófico estrecho. La dieta de jóvenes y adultos de $E$. lineatus presentó diferencias alimentarias de acuerdo con su crecimiento, contrario a lo observado entre jóvenes y adultos de $S$. sierra. Entre temporadas climáticas, la dieta no presentó variaciones significativas en ambas especies. Asimismo, el valor de traslape trófico obtenido entre ambas especies fue bajo. El nivel trófico determinado para ambas especies indicó que son consumidores terciarios. Conclusiones: El barrilete negro Euthynnus lineatus y la sierra del Pacifico Scomberomorus sierra son depredadores terciarios y presentan un comportamiento especialista, principalmente sobre peces de las familias Engraulidae y Clupeidae. Aunque se observó una similitud en los componentes alimentarios de estas especies, no existe un alto grado de competencia interespecífica por el alimento.

Palabras clave: dieta; barrilete negro; sierra del Pacífico; amplitud del nicho; nivel trófico; competencia; Pacífico Oriental Tropical. 


\section{REFERENCES}

Aguirre-Villaseñor, H., Morales-Bojórquez, E., MoránAngulo, R.E., Madrid-Vera, J., \& Valdez-Pineda, M.C. (2006). Indicadores biológicos de la pesquería de sierra (Scomberomorus sierra) al sur del Golfo de California, México. Ciencias Marinas, 32(3), 471-484.

Allen, G.R., \& Robertson, D.R. (1994). Fishes of the Tropical Eastern Pacific. USA: University of Hawaii Press.

Arrington, A., Winemiller, K.O., Loftus, W.F., \& Akin, S. (2002). How often do fishes "run on empty"? Ecology, 83(8), 2145-2151.

Artunduaga, P.E. (1972). La Sierra (Scomberomorus sierra; Jordan y Starks) del Pacífico Colombiano. Divulgación Pesquera, 8(4), 72.

Bahou, L., Koné, T., N’Douba, V., N'Guessan, K.J., Kouamélan, E.P., \& Gouli, G.B. (2007). Food composition and feeding habits of little tunny (Euthynnus alletteratus) in continental shelf waters of Côte d'lvoire (West Africa). ICES Journal of Marine Science, 64, 1044-1052.

Bakhoum, S.A. (2007). Diet overlap of immigrant narrowbarred Spanish mackerel Scomberomorus commerson (Lac., 1802) and the largehead hairtail ribbonfish Trichiurus lepturus (L., 1758) in the Egyptian Mediterranean coast. Animal Biodiversity and Conservation, $30(2), 147-160$.

Bizzarro, J.J., Robison, H.J., Rinewalt, C.S., \& Ebert, D.A. (2007). Comparative feeding ecology of four sympatric skate species off central California, USA. Environmental Biology of Fishes, 80(2/3), 221-237.

Brown, S.C., Bizzarro, J.J., Cailliet, G.M., \& Ebert, D.A. (2011). Breaking with tradition: redefining measures for diet description with a case study of the Aleutian skate Bathyraja aleutica (Gilbert 1896). Environmental Biology of Fishes, 95(1), 3-20.

Caragitsou, E., \& Papaconstantinou, C. (1993). Feeding habits of piper (Trigllyra) in the Saronikos Gulf (Grece). Journal Applied Ichthyology, 10, 104-113. DOI: 10.1111/j.1439 426.1994.tb00149.x

Chiou, W.D., \& Lee, L.K. (2004). Migration of kawakawa Euthynnus affinis in the waters near Taiwan. Fisheries Science, 70, 746-757.

Christensen, V., \& Pauly, D. (1992). ECOPATH II - a software for balancing steady-state models and calculating network characteristics. Ecological Modelling, 61, 169-185.

Clothier, C.R. (1950). A key to some southern California fishes based on vertebral characters. Fishery Bulletin, $79,1-83$.

Collette, B.B., \& Nauen, C.E. (1983). FAO species catalogue. Vol. 2. Scombrids of the world. An annotated and illustrated catalogue of tunas, mackerels, bonitos and related species known to date. Food and Agriculture Organization, Fishery Synopsis, 125(2), 137p.

Cortés, E. (1999). Standardized diet compositions and trophic levels of sharks. ICES Journal Marine Science, 56(5), 707-717.

Cortés, E., Papastamatiou, Y., Carlson, J., Ferry, G.L., \& Wetherbee, B. (2008). An overview of the feeding ecology and physiology of elasmobranch fishes. In J.E.P. Cyrino, D.P. Bureau, \& B.G. Kapoor (Eds.), Feeding and Digestive Functions of Fish (pp. 393443). Enfield, NH: Science Publishers.

Ehemann, N.R., Abitia-Cardenas, L.A., Navia, A.F., MejíaFalla, P.A., \& Cruz-Escalona, V.H. (2019). Zeros as a result in diet studies, is this really bad? Rhinoptera steindachneri as a case study. Journal of the Marine Biological Association of the United Kingdom, 1-6. DOI: $10.1017 / \mathrm{mS} 0025315419000511$

FAO (Organización de las Naciones Unidas para la Agricultura y la Alimentación). (1994). Examen de la situación mundial de las especies altamente migratorias y las poblaciones transzonales (Documento Técnico de Pesca No. 337). Roma: FAO. Retrieved from http://www.fao.org/3/t3740s/t3740s00.htm

Fischer, W., Krupp, F., Schneider, W., Sommer, C., Carpenter, K.E., \& Niem, V.H. (1995). Guía FAO para la identificación de especies para los fines de la pesca. Pacífico Centro-Oriental. Vol. I-III. Roma, FAO. (1-3), 1-1813.

Flores-Martínez, I.A., Torres-Rojas, Y.E., Galván-Magaña, F., \& Ramos-Miranda, J. (2016). Diet comparison between silky sharks (Carcharhinus falciformis) and scalloped hammerhead sharks (Sphyrna lewini) off the south-west coast of Mexico. Journal of the Marine Biological Association of the United Kingdom, 97, 337-345.

Gotelli, N.J., Hart, E.M., \& Ellison, A.M. (2014). EcoSimR (Version. 0.1.0, R Package). Retrieved from https:// github.com/GotelliLab/EcoSimR/issues

Griffiths, S.P., Kuhnert, P.M., Fry, G.F., \& Manson, F.J. (2009). Temporal and size-related variation in the diet, consumption rate, and daily ration of mackerel tuna (Euthynnus affinis) in neritic waters of eastern Australia. ICES Journal of Marine Science, 66, 720-733.

Gutiérrez-Zabala, R.M., \& Cabrera-Mancilla, E. (2012). La pesca ribereña de Guerrero. México: Instituto Nacional de Pesca.

Hernández-Aguilar, S.B., Abitia-Cárdenas, L.A., MorenoSánchez, X.G., Arellano-Martínez, M., \& González-Rodríguez, E. (2012). Trophic spectrum of the sailfish Istiophorus platypterus caught off Acapulco in the southern Mexican Pacific. Journal of the 
Marine Biological Association of the United Kingdom, 1-8. DOI:10.1017/S0025315412001622

Horn, H.S. (1966). Measurement of overlap in comparative ecological studies. American Naturalist, 100, 419-424.

Hyslop, E.J. (1980). Stomach contents analysis, a review of methods and their application. Journal of Fish Biology, 17, 411-429. DOI: 10.1111/j.1095-8649.1980. tb02775.x

Krebs, C.J. (1999). Ecological methodology. E.U.A.: Addison Wesley Longman.

Leigh, S.C., Papastamatiou, Y., \& German, D.P. (2017). The nutritional physiology of sharks. Reviews in Fish Biology and Fisheries, 27, 561-585.

Ménard, F., Labrune, C., Shin, Y.J., Asine, A.S., \& Bard, F.X. (2006). Opportunistic predation in tuna: a sizebased approach. Marine Ecology Progress Series, 323, 223-231.

Miranda-Delgado, J.E., Violante-González, J., Monks, S., Rojas-Herrera, A.A., García-Ibáñez, S., Flores-Rodríguez, P., Romero-Ramírez, Y., \& Santos-Bustos, N.G. (2019). Factors linked to interannual variation in the metazoan parasite communities of black skipjack, Euthynnus lineatus (Pisces:Scombridae). Invertebrate Biology, 00:e12259, 1-18.

Montemayor-López, G., \& Cisneros-Mata, M.A. (2000). La sierra del Golfo de California. In Sustentabilidad y pesca responsable en México; evaluación y manejo 1997-1998. Instituto Nacional de la Pesca (259-274). México: Secretaria de Medio Ambiente y Recursos Naturales (SEMARNAT).

Moreno-Sánchez, X.G., Quiñonez-Velázquez, C., AbitiaCárdenas, L.A., \& Rodríguez-Romero, J. (2012). Diet of the Pacific sierra Scomberomorus sierra (Perciformes: Scombridae) in two areas of north-west Mexico coast. Aqua, 17(4), 1-15.

Naughton, S.P., \& Saloman, C.H. (1981). Stomach Contents of Juveniles of King Mackerel (Scomberomorus cavalla) and Spanish Mackerel (S. maculatus). Northeast Gulf Science, 5(1), 71-74. DOI: 10.18785/ negs.0501.12

Oksanen, J. (2016). Vegan Community Ecology Package (Version 2.4-1, R Package). Retrieved from https:// github.com/vegandevs/vegan

Olson, R.J., Duffy, L.M., Kuhnert, P.M., Galván-Magaña, F., Bocanegra-Castillo, N., \& Alatorre-Ramírez, V. (2014). Decadal diet shift in yellowfin tuna Thunnus albacares suggests broad-scale food web changes in the eastern tropical Pacific Ocean. Marine Ecology Progress Series, 497, 157-178.
Olson, R.J., Young, J.W., Ménard, F., Potier, M., Allain, V., Goñi, N., Logan, J.M., \& Galván-Magaña, F. (2016). Bioenergetics, trophic ecology, and niche separation of tunas. In B.E. Curry (Ed.), Advances in Marine Biology (pp. 199-344). U.K.: Academic Press.

Palacios-Salgado, D.S., Ramírez-Valdez, A., Rojas-Herrera, A.A., Granados-Amores, J., \& Melo-García, M.A. (2014). Marine fishes of Acapulco, Mexico (Eastern Pacific Ocean). Marine Biodiversity, 44(4), 472-490. DOI: $10.1007 / \mathrm{s} 12526-014-0209-4$

Pace, M.L., Cole, J.J., Carpenter, S.R., \& Kitchell, J.F. (1999). Trophic cascades revelated in diverse ecosystems. Trends in Ecology and Evolution, 14(12), 483-488.

R Core Team. (2015). R: A language and environment for statistical computing. R Foundation for Statistical Computing, Vienna, Austria. Retrieved from http:// www.R-project.org

Rojas-Herrera, A.A., Mascaró, M., \& Chiappa-Carrara, X. (2004). Hábitos alimentarios de los peces Lutjanus peru y Lutjanus guttatus (Pisces: Lutjanidae) en Guerrero, México. Revista de Biología Tropical, 52(4), 959-971.

Ruíz-Pérez, N.E., Cerdenares-Ladrón de Guevara, G., López-Herrera, D.L., \& Altamirano-Ramírez, I.R. (2016). Relaciones tróficas entre cinco especies de peces pelágicos que cohabitan en las costas de Oaxaca, México. Hidrobiológica, 26(1), 77-85.

Saucedo-Lozano, M., Bernal-Omelas, I.H., Espino-Barr, E., García-Boa, A., Cabral-Solís, E.G., \& PuenteGómez, M. (2012). Feeding habits of the green jack (Caranx caballus Gunther, 1868) on the Coast of Manzanillo, Colima, Mexico). The Open Marine Biology Journal, 6, 28-37.

Schaefer, K.M. (1984). Swimming performance, body temperatures and gastric evacuation times of the Black skipjack, Euthynnus lineatus. Copeia, 4, 1000-1005.

Schaefer, K.M. (1987). Biología reproductiva del barrilete negro, Euthynnus lineatus, un atún del Pacífico Oriental. Inter-American Tropical Tuna Commission Bulletin, 19(2), 229-260.

Sea Around Us project. (2016). Marine Trophic Index. Retrieved from http://www.seaaroundus.org/data/\#/ marine-trophic-index

Smith, P.E., \& Zaret, M.T. (1982). Bias in estimating niche overlap. Ecology, 63, 1248-1253.

Wetherbee, B.M., Cortés, E., \& Bizarro, J.J. (2012). Food consumption and feeding habits. In J.F. Carrier, J.A. Musick, \& M. Heithaus (Eds.), Biology of Sharks and their Relatives (pp. 239-264). Boca Raton, FL: CRC Press. 